A1-Amwal: Journal of Islamic Economic Law April 2018, Vol. 3, No. 1

http://www.iainpalopo.ac.id/index.php/alamwal

\title{
PENGELOLAAN ZAKAT DALAM TINJAUAN UU RI NO. 23 TAHUN 2014 TENTANG PEMERINTAHAN DAERAH
}

\author{
Muh. Ruslan Abdullah \\ Fakultas Syariah IAIN Palopo \\ Email : ruslaniainpalopo@gmail.com
}

\begin{abstract}
Based on data obtained from BAZNAS, Indonesia has a zakat potential of 217 trillion per year, but its realization is only about $R p 6$ trillion per year. This condition requires the government to think about how to effectively increase the collection of zakat. One of the strategic steps taken by the government is to issue Law No. 23 of 2011 on the Management of Zakat. However, the law has not been able to maximize the performance of BAZNAS/LAZ and persuade people to pay zakat. On the contrary, Law No. RI. 23 of 2014 Regarding local governance can improve the management of zakat in BAZNAS, and sanction against muzakki who do not give the zakat.
\end{abstract}

Keywords: Zakat Management, Local Governance

\section{Abstrak}

Berdasarkan data dari BAZNAS, Indonesia memeliki Potensi zakat sebesar 217 triliun per tahun, namun realisasinya hanya mencapai sekitar $R p 6$ triliun pertahun. Kondisi ini menuntut pemerintah untuk berpikir mencari cara efektif meningkatkan penghimpunan zakat. Salah satu langkah strategis yang dilakukan pemerintah adalah dengan menerbitkan Undang-Undang Nomor 23 Tahun 2011 tentang Pengelolaan Zakat. Namun, UU tersebut belum dapat memaksimalkan kinerja BAZNAS / LAZ dan membujuk orang untuk membayar zakat. Sebaliknya, UU RI No. 23 Tahun 2014 Tentang pemerintahan daerah dapat meningkatkan pengelolaan zakat di BAZNAS, dan pemberian sanksi terhadap muzakki yang tidak memberi zakat.

Kata Kunci: Pengelolaan zakat, Pemerintah daerah

\section{PENDAHULUAN}

Zakat adalah salah satu sektor penting dalam filantropi Islam. Sebagai rukun Islam ketiga, zakat wajib dibayarkan oleh setiap Muslim yang memenuhi syarat (muzakki) untuk menyucikan hartanya dengan cara menyalurkan zakatnya kepada mustahik (penerima zakat). Zakat ini tidak hanya berfungsi untuk menolong perekonomian mustahik, tetapi juga dapat menjadi instrumen penyeimbang dalam sektor ekonomi nasional. Dalam jangka panjang, tujuan utama zakat adalah mentransformasi 
para mustahik menjadi muzakki. Hal ini menunjukkan bahwa zakat sangat berpotensi untuk mengatasi kesenjangan ekonomi dan kemiskinan di suatu Negara. ${ }^{1}$

Potensi zakat di Indonesia sangat besar. Hal tersebut juga sudah disadari oleh pemerintah, dalam hal ini Kementerian BAPPENAS, yang telah mengintegrasikan program-program zakat di OPZ ke dalam program nasional pencapaian SDGs (Sustainable Development Goals). Selain itu, BAPPENAS juga memasukkan zakat ke dalam Masterplan Arsitektur Keuangan Syariah Indonesia (MAKSI) yang diluncurkan pada tahun 2015. Berdasarkan MAKSI, BAZNAS diarahkan sebagai koordinator dalam pengaturan, pengumpulan, dan distribusi zakat nasional, dengan Kementerian Agama sebagai regulator dan pengawas kinerja BAZNAS. ${ }^{2}$

Potensi zakat di Indonesia mencapai Rp 217 triliun pertahun, namun realisasi penggalangan dari berbagai BAZNAS baru mencapai Rp 6 triliun. ${ }^{3}$ Potensi zakat yang besar belum didukung oleh penghimpunan dana zakat di lapangan. Kesenjangan ini dipengaruhi oleh beberapa hal, seperti: ${ }^{4}$

1. Rendahnya kesadaran wajib zakat (muzakki), rendahnya kepercayaan terhadap BAZ dan LAZ, dan perilaku muzakki yang masih berorientasi jangka pendek, desentralis dan interpersonal.

2. Basis zakat yang tergali masih terkonsentrasi pada beberapa jenis zakat tertentu, seperti zakat fitrah dan profesi.

3. Masih rendahnya insentif bagi wajib zakat untuk membayar zakat, khususnya terkait zakat sebagai pengurang pajak sehingga wajib zakat tidak terkena beban ganda.

Pelaksanaan otonomi, sebagai salah satu pilihan sistem yang dapat digunakan oleh pemerintah untuk mempercepat terciptanya kesejahteraan masyarakat. ${ }^{5}$ UU RI NO. 23

1 Divisi Publikasi Dan Jaringan Pusat Kajian Strategis (Puskas) BAZNAS, Outlook Zakat Indonesia 2017 (Jakarta: BAZNAS 2017), h. 1

2 Divisi Publikasi Dan Jaringan Pusat Kajian Strategis (Puskas) BAZNAS, Outlook Zakat Indonesia 2017 (Jakarta: BAZNAS 2017), h. 5.

3 Ichwan Chasani, Judul Potensi Zakat Rp217 Triliun Bisa Dongkrak Pertumbuhan Ekonomi, http://wartakota.tribunnews.com/2017/07/26/potensi-zakat-rp217-triliun-bisa-dongkrakpertumbuhan-ekonomi, diakses pada tanggal 10 Maret 2018

4 Divisi Publikasi Dan Jaringan Pusat Kajian Strategis (Puskas) BAZNAS, Outlook Zakat Indonesia 2017 (Jakarta: BAZNAS 2017), h. 6.

${ }^{5}$ M. Makhfudz, Kontroversi Pelaksanaan Otonomi Daerah. Adil : Jurnal Hukum Vol. 3 No.2, h. 380 
Tahun 2014 tentang Pemerintah Daerah menjelaskan bahwa penyelenggaraan pemerintahan daerah diarahkan untuk mempercepat terwujudnya kesejahteraan masyarakat melalui peningkatan pelayanan, pemberdayaan, dan peran serta masyarakat, serta peningkatan daya saing daerah dengan memperhatikan prinsip demokrasi, pemerataan, keadilan, dan kekhasan suatu daerah dalam sistem Negara Kesatuan Republik Indonesia. Peningkatan kesejahteraan masyarakat dapat dilakukan dengan mengoptimalkan pengelolaan zakat, sebagaimana yang diungkapkan oleh Abdurahman A. Basalamah bahwa Zakat sebagai Alat bukan tujuan, sehingga mengandung metode dan fleksibilitas yang tinggi. Sasaran yang dikehendaki adalah kemaslahatan dan kesejahteraan umat. Zakat juga mendorong motovasi dan kreativitas umat sehingga umat dapat mengubah kondisi derajat ekonominya. Olehnya itu zakat harus dioptimalkan dengan dukungan dari berbagai pihak terutama pemerintah dan umat. Sehingga terwujud pemerintah yang arif dan bijaksana yang mampu menyelesaikan problem kemiskinan dan kefakiran. ${ }^{6}$

I Made Murjana yang memaparkan bahwa Otonomi daerah merupakan upaya meningkatkan kesejahtraan masyarakat melalui memaksimalkan potensi sumber daya alam dan sumber daya manusia, serta memaksimal pengelolaannya sehingga tujuan otonomi daerah dapat direalisasikan dengan baik. Untuk mewujudkannya maka perlu pengawasan, baik secara internal dari pemerintah melalui Kementrian Dalam Negeri juga partisipasi masyarakat di daerah terutama masyarakat sipil seperti lembaga swadaya masyarakat maupun organisasi sosial keagamaan yang ada. ${ }^{7}$

Yulia Devi Ristanti dan Eko Handoyo dalam tulisannya menjelaskan Otonomi daerah sudah diatur dalam undang-undang Negara Republik Indonesia No 32 tahun 2004 dan no 23 tahun 2014. Otonomi daerah merupakan hak, wewenang, dan kewajiban daerah otonom untuk mengatur dan mengurus daerahnya sendiri, baik berurusan pemerintahan dan kepentingan masyarakat. Kegiatan-kegiatan yang dapat diatur oleh daerah adalah termasuk peraturan perekonomian. ${ }^{8}$

\footnotetext{
${ }^{6}$ Lihat,- Abdurahman A. Basalamah, Ekonomi Bulan sabit, h. 31-33

7 I Made Murjana, Pelaksanaan Dan Permasalahan Otonomi Daerah Menurut Undang-Undang No.32 Tahun 2004 (Tinjauan Teoritis) Ganeç Swara Vol. 10 No.1 Maret 2016

${ }^{8}$ Yulia Devi Ristanti Dan Eko Handoyo, Undang-Undang Otonomi Daerah Dan Pembangunan Ekonomi Daerah. Jurnal Riset Akutansi Keuangan Volume 2 No.2 April 2017
} 
M. Makhfudz menjelaskan bahwa Pelaksanaan otonomi, sebagai salah satu pilihan sistem yang dapat digunakan oleh pemerintah untuk mempercepat terciptanya kesejahteraan masyarakat. Karena otonomi adalah sebagai usaha membagi rata tanggung jawab pemerintahan pusat. Kemudian beban tanggung jawab dibagi ke pemerintahan lokal, sampai yang paling bawah. Demikianlah juga sebagai media pendidikan politik, yaitu dengan meningkatkan pengertian rakyat serta dukungan mereka dalam kegiatan usaha pembangunan sosial ekonomi, sehingga diharapkan masyarakat bawah dapat merasakan keuntungan dari konstribusi kegiatan usaha mereka. Makalah ini disusun berdasarkan pelaksanaan penelitian yang dilakukan secara deskriptif, dan melakukan analisis normatif dengan membandingkan dengan kenyataan di lapangan yang ditemui pada lokasi penelitian. ${ }^{9}$

I Gusti Ngurah Suryaadi Mahardika dan Luh Gede Sri Artini dari hasil penelitian menemukan bahwa otonomi berpengaruh signifikan terhadap kemandirian daerah. Sehingga dengan otonomi daerah dapat mendorong upaya peningkatan kapasitas daerah itu sendiri. BAZNAS dan LAZ adalah salah satu institusi yang dapat menggerakkan kemandirian ekonom di daerah otonom.

Tulisan ini mencoba menganalisa fungsi dan tanggung jawab pemerintah daerah dalam Undang-Undang RI No. 23 Tahun 2014 Tentang Pemerintahan Daerah, serta memadukan dengan pengelolaan zakat, sehingga tergambar pengelolaan zakat di daerah otonom. Artikel ini adalah murni kualitatif yang menitikberatkan pada kajian pustaka disertai lealitas pengelolaan zakat di daerah.

Latar belakang di atas mengarahkan penulis untuk menarik rumusan masalah yakni: Bagaimana Eksistensi pengelolaan zakat dalam pemerintahan daerah?

\section{METODE}

Tulisan ini merupakan studi literatur yang meninjau manajemen zakat serta mengkaji UU RI no. 23 Tahun 2014 tentang Pemerintahan Daerah. Pendekatan yang digunakan adalah hukum dan kebijakan ekonomi. Analisis data yang digunakan adalah analisis deskripsi kualitatif.

\footnotetext{
${ }^{9}$ M. Makhfudz, Kontroversi Pelaksanaan Otonomi Daerah, Adil : Jurnal Hukum Vol. 3 No.2
} 


\section{PEMBAHASAN}

\section{A. Pemerintah Daerah Otonom}

Salah satu sektor yang sangat menarik dikaji dalam ekonomi Islam adalah sektor yang berkaitan dengan tanggung jawab pemerintah muslim di bidang keuangan dan ekonomi, tanggung jawab pemerintah di bidang ekonomi dapat di bagi menjadi dua bagian $:^{10}$

1. Tanggung jawab untuk memenuhi kebutuhan kaum fakir miskin

2. Tanggung jawab untuk memberikan petunjuk atau bimbingan di berbagai sektor produksi dan distribusi.

Pasal 17 ayat 1 dalam UU RI NO. 23 Tahun 2014 menjelaskan bahwa daerah berhak menetapkan kebijakan Daerah untuk menyelenggarakan Urusan Pemerintahan yang menjadi kewenangan Daerah. Pasal 22 ayat 1 Daerah berhak menetapkan kebijakan daerah dalam melaksanakan tugas pembantuan. Pasal 31 ayat 1 menjelaskan bahwa dalam pelaksanaan desentralisasi dilakukan penataan daerah. Pada ayat 2 menjelaskan Penataan Daerah sebagaimana dimaksud pada ayat 1 ditujukan untuk: a) mewujudkan efektivitas penyelenggaraan Pemerintahan Daerah; b) mempercepat peningkatan kesejahteraan masyarakat; c) mempercepat peningkatan kualitas pelayanan publik; d) meningkatkan kualitas tata kelola pemerintahan; e) meningkatkan daya saing nasional dan daya saing Daerah; dan f) memelihara keunikan adat istiadat, tradisi, dan budaya daerah.

Persyaratan dasar kapasitas Daerah sebagaimana dimaksud Pasal 22 ayat 1 huruf b dalam UU RI NO. 23 Tahun 2014 adalah kemampuan daerah untuk berkembang dalam mewujudkan kesejahteraan masyarakat. Pada Pasal 58 menjelaskan Penyelenggara Pemerintahan Daerah, sebagaimana dimaksud dalam Pasal 57, dalam menyelenggarakan Pemerintahan Daerah berpedoman pada asas penyelenggaraan pemerintahan Negara yang terdiri atas: a. kepastian hukum; b. tertib penyelenggara negara; c. kepentingan umum; d. keterbukaan; e. proporsionalitas; f. profesionalitas; g. akuntabilitas; h. efisiensi; i. efektivitas; dan j. keadilan.

\footnotetext{
${ }^{10}$ Muhammad Husaini Bahesyti Dan Jawad Bahonar, Intisari Islam Kajian Komprehensif Tentang Hikmah Ajaran Islam. Cet. 1 (Jakarta; Lentera, 2003), h. 433
} 
Tugas pemerintah daerah terdapat pada pasal 65 ayat 1 salah satunya adalah pemerintah daerah memimpin pelaksanaan urusan pemerintahan yang menjadi kewenangan Daerah berdasarkan ketentuan peraturan perundang-undangan dan kebijakan yang ditetapkan bersama DPRD. Pada ayat 2 pemerintah daerah dalam melaksanakan tugas sebagaimana dimaksud pada ayat 1 kepala daerah berwenang: a) mengajukan rancangan Perda; b) menetapkan Perda yang telah mendapat persetujuan bersama DPRD; c) menetapkan Perkada dan keputusan kepala daerah; d) mengambil tindakan tertentu dalam keadaan mendesak yang sangat dibutuhkan oleh Daerah dan/atau masyarakat; e) melaksanakan wewenang lain sesuai dengan ketentuan peraturan perundang-undangan.

\section{B. Otonomi Daerah dan Kemandirian Ekonomi}

Asfek keadilan yang diukur dengan tingkat kesejahteraan dewasa ini, hanya mengandalkan peran pemerintah dalam melakukan pemerataan melalui pajak dan pemberian pelayanan umum (sosial ekonomi), hasil akhir yang dicapai tetap memperlihatkan adanya ketimpangan yang makin tajam, antara si kaya dan si miskin. Ketimpangan ini di sebabkan karena moral, dan hukum ekonomi tidak mengandung muatan hakiki keadilan (keridhaan, manfaat dan kejelasan). ${ }^{11}$

Pasal 1 UU RI No. 23 Tahun 2014 tentang Pemerintah Daerah menjelaskan Pemerintahan Daerah adalah penyelenggaraan urusan pemerintahan oleh pemerintah daerah dan dewan perwakilan rakyat daerah menurut asas otonomi dan tugas pembantuan dengan prinsip otonomi seluas-luasnya dalam sistem dan prinsip Negara Kesatuan Republik Indonesia sebagaimana dimaksud dalam Undang-Undang Dasar Negara Republik Indonesia Tahun 1945. selanjutnya Pemerintah Daerah disebutkan sebagai kepala daerah sebagai unsure penyelenggara Pemerintahan Daerah yang memimpin pelaksanaan urusan pemerintahan yang menjadi kewenangan daerah otonom. Pada pasal 1 poin 6 menjelaskan bahwa Otonomi Daerah adalah hak, wewenang, dan kewajiban daerah otonom untuk mengatur dan mengurus sendiri Urusan Pemerintahan dan kepentingan masyarakat setempat dalam sistem Negara Kesatuan Republik Indonesia.

${ }^{11}$ Abdurahman A. Basalamah, Ekonomi Bulan Sabit, Gerakan Pembagunan Dalam Konsep Islam (Ujung Pandang; PT. Umitoha Ukhuwah Grafika, 1996), h. 4 
Pasal 12 ayat 1 menjelaskan bahwa urusan Pemerintahan Wajib yang berkaitan dengan Pelayanan Dasar sebagaimana dimaksud dalam Pasal 11 ayat (2) meliputi: a. pendidikan; b. kesehatan; c. pekerjaan umum dan penataan ruang; d. perumahan rakyat dan kawasan permukiman; e. ketenteraman, ketertiban umum, dan pelindungan masyarakat; dan f. sosial.

Ayat 2 menjelaskan bahwa urusan Pemerintahan Wajib yang tidak berkaitan dengan Pelayanan Dasar sebagaimana dimaksud dalam Pasal 11 ayat (2) meliputi: a. tenaga kerja; b. pemberdayaan perempuan dan pelindungan anak; c. pangan; d. pertanahan; e. lingkungan hidup; f. administrasi kependudukan dan pencatatan sipil; g. pemberdayaan masyarakat dan Desa; h. pengendalian penduduk dan keluarga berencana; i. perhubungan; j. komunikasi dan informatika; k. koperasi, usaha kecil, dan menengah; 1. penanaman modal; m. kepemudaan dan olah raga; $\mathrm{n}$. statistik; $\mathrm{o}$. persandian; p. kebudayaan; q. perpustakaan; dan r. kearsipan.

Undang-Undang RI No. 23 Tahun 2014 tentang pemerintah daerah telah menjelaskan bahwa pemerintah daerah memiliki kewenangan dalam mengurus daerah sendiri sepanjang kebijakan pemerintah daerah tidak bertentangan dengan aturan lain. Otonomi daerah mengarahkan pada kemandirian pemerintah, masyarakat dalam meningkatkan produktivitas pelayanan dan produktivitas ekonomi pemerintah dan masyarakat, sehingga tercipta masyarakat yang makmur dan sejahtera.

\section{Peluang Pengelolaan Zakat Versi Otonomi Daerah}

Secara bahasa zakat kata dasar (masdar)-nya zaka yang berarti berkah, tumbuh, bersih, baik, dan bertambah. Bagi orang yang mengeluarkan zakat, hati dan jiwanya akan bersih, sebagaimana firman Allah Swt. Dalam surah at-Taubah ayat 103. Selain hati dan jiwanya bersih, kekayaannya akan bersih pula. Dari ayat ini tergambar bahwa zakat yang dikeluarkan oleh para muzaki akan dapat membersihkan dan menyucikan hati manusia, tidak lagi mempunyai sifat yang tercela terhadap harta, seperti rakus dan kikir. $^{12}$

${ }^{12}$ Dewan Redaksi Ensiklopedi Islam, Ensiklopedi Islam. Cet. 3 (Jakarta: Ictiar Baru Van Hoeve, 1994), H. 224. Bandingkan Dengan Cyril Glasse, Ensiklopedi Islam (Ringkas) Cyril Glasse, Cet. 3 (Jakarta; PT. Raja Grafindo Persada, 2002), H. 445. Dan Lihat; Bandingkan Dengan Majma' Lughah AlArabiyah, Mu'jam Al-Wasit, Juz I (Mesir; Dar Al-Ma'arif, 1972), h. 396 
Rendahnya nilai perilaku ekonomi baik personal lebih-lebih moral dan tak adanya pengawasan akan membawa kerusakan ekonomi masyarakat. Sebagaimana dalam QS.Al-Taubah; (9): 103

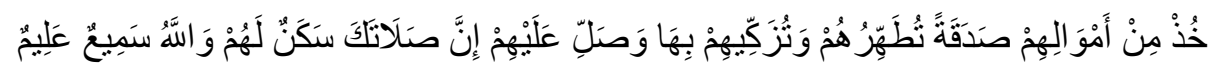

Terjemahnya;

103. Ambillah zakat dari sebagian harta mereka, dengan zakat itu kamu membersihkan[658] dan mensucikan[659] mereka dan mendoalah untuk mereka. Sesungguhnya doa kamu itu (menjadi) ketenteraman jiwa bagi mereka. dan Allah Maha mendengar lagi Maha Mengetahui. ${ }^{13}$

Ayat ini tegas menyatakan perintah kepada Rasul selain sebagai Nabi ia juga bertugas melaksanakan hukum-hukum Allah dalam masyarakat untuk mewujudkan kesejahteraan dan kesentosaan rakyat yang juga merupakan tujuan ekonomi yang di kehendaki Al-Qur'an. Tugas-tugas demikian dilaksanakan oleh khalifah sebagai kepala pemerintahan. Dari sini dapat dipahami bahwa pemerintah adalah juga pelaku ekonomi, bahkan yang lebih kuat karena di tangannyalah terletak penentuan kebijakan ekonomi.

Salah satu kebijakan ekonomi yang dapat dipahami dari ayat di atas adalah perintah kepada nabi agar beliau berupaya memberi ketentraman kepada masyarakat. Ini berarti pemerintah harus aktif mewujudkan dan memelihara ketentraman masyarakat. Ini dapat terwujud jika dalam masyarakat terdapat faktor-faktor dan sarana ekonomi yang memadai dan kondisi sosial ekonomi dan keamanan yang mapan. ${ }^{14}$

Zakat bukan tujuan akan tetapi sebagai sarana dalam meningkatkan kesjahteraan. Tujuan pengelolaan zakat yang diinginkan adalah kebahagiaan dunai dan akhirat. Zakat mendorong motovasi dan kreasi masyarakat dalam pemilikan dan penggunaan harta kekayaan. Olehnya itu zakat harus ditegakkan dengan dukungan yang terpadu dari masyarakat dan pemerintah. Tergambar pemerintah yang arif dan bijaksana akan memahami peran zakat, yang mampu menyelesaikan masalah kemiskinan dan kefakiran serta perilaku negatif yang dapat ditimbulkan ${ }^{15}$

13 Al-Qur'an Dan Terjemahan. [658] Maksudnya: Zakat Itu Membersihkan Mereka Dari Kekikiran Dan Cinta Yang Berlebih-Lebihan Kepada Harta Benda. [659] Maksudnya: Zakat Itu Menyuburkan Sifat-Sifat Kebaikan Dalam Hati Mereka Dan Memperkembangkan Harta Benda Mereka

${ }^{14}$ Abd Muin Salim, Ekonomi Dalam Perspektif Al-Qur'an, Sebuah Pengantar Pengenalan Dasar Ekonomi Islam, (Ujung Pandang; Yayasan Kesejahteraan Islam YAKIS Syariah, 1994), h. 9

${ }^{15}$ Lihat,- Abdurahman A. Basalamah, Ekonomi Bulan Sabit, h. 31-33 
Zakat mewujudkan kemandirian sosial tidak sama dengan suatu kewajiban membayar pajak bagi warga negara. Ini merupakan kewajiban agama secara mutlak dari Tuhan Yang Maha Pencipta kepada umat manusia sebagai amanah untuk mengeluarkan kekayaan yang telah Dia anugerahkan sebagai bentuk keimanan, ditunaikan kepada orang yang kurang beruntung. Ini merupakan salah satu bentuk ketentuan peribadatan yang dalam Islam tidak hanya meliputi shalat, puasa dan haji; tetapi juga mencakup pemenuhan kewajiban kepada orang lain. Salah satu cara untuk mengerjakan kewajiban itu, yang di tuntut Islam dari kaum Muslim, adalah melalui intitusi zakat, yang merupakan bagian yang tidak terpisah dari keimanan. Zakat adalah tanda yang jelas dan tegas dari kehendak Tuhan untuk menjamin bahwa tidak seorang pun menderita kekurangan sarana untuk memenuhi kebutuhan pokok akan barang dan jasa. ${ }^{16}$

Pembangunan versi Islam bersifat multi-dimensi yang meliputi aspek fizikal, kerohanian dan moral. Pembangunan dalam kerangka pemikiran Islam bersandar pada konsep tauhid. Allah pemilik mutlak dan manusi amanahkan sebagai pemimpin yang memiliki tugas dan bertanggungjawab membangunkan alam semesta berlandaskan kepada al-Quran dan as-Sunnah. ${ }^{17}$ Akan tetapi ironisnya adalah Indonesia adalah mayoritas penduduknya beragama Islam akan tetapi system ekonomi yang dibangun adalah system neoliberal. System ekonomi dan pemerintah Indonesi juga kadangkala tidak jelas tergantung siapa pemimpinnya. Sehingga muncul istilah "pemimpin berganti, system pun berganti”

Islam menghendaki kesejahteraan secara menyeluruh Individu, keluarga, masyarakat dan bangsa, terpadu antara rohaniah dan jasmaniah. Hal ini tergambar dari perintah Allah Swt., dalam Al-Qur'an; perintah berkorban dan shalat, serta perintah Zakat. Jelas terdapat keterpaduan antara aspek ekonomi dan sosial. ${ }^{18}$

Secara umum pembangunan ekonomi merupakan persyaratan utama untuk mewujudkan kesejahteraan dan kemajuan bangsa. Karena itu pembangunan harus menyentuh semua aspek yang terkait, sehingga dapat memapankan pertumbuhan yang

\footnotetext{
${ }^{16}$ M. Umer Chapra, Islam Dan Tantangan Ekonomi; Islam Ekonomi Konterporer (Surabaya; Risalah Gusti, 1999), h. 292-293

17 Nor Sahida Mohamad, Pembangunan Menurut Perspektif Islam: Satu Analisis Awalan (Development from Islamic Perspective: An Interim Analysis), Prosiding Persidangan Kebangsaan Ekonomi Malaysia Ke VIII JILID 1 (2013) 355 - 370

${ }^{18}$ Ibid,- 23
} 
berkelanjutan (subtainable growth). Persyaratan struktural yang perlu diperhatikan dalam upaya untuk memapankan pertumbuhan sektor ekonomi, adalah keserasian perimbangan antar sektor-sektor ekonomi itu sendiri. ${ }^{19}$

UU No. 23 Tahun 2011 berfungsi sebagai dasar pelaksanaan dan pengelolaan zakat di Indonesia. Pengelolaan zakat ini bertujuan untuk "meningkatkan efektivitas dan efisiensi pelayanan dalam pengelolaan zakat, dan meningkatkan manfaat zakat untuk mewujudkan kesejahteraan masyarakat dan penanggulangan kemiskinan” (Pasal 3). Dalam UU ini, BAZNAS ditunjuk sebagai lembaga pemerintah nonstruktural yang bersifat mandiri dan bertanggung jawab kepada Presiden melalui Menteri Agama (Pasal 5). Secara umum, BAZNAS memiliki dua tugas utama: (1) mengelola keseluruhan sistem zakat yang meliputi perencanaan, pelaksanaan, pengendalian pengumpulan, pendistribusian, dan pendayagunaan zakat, serta pelaporan dan pertanggungjawaban pelaksanaan pengelolaan zakat, (2) melaksanakan fungsi koordinasi terhadap seluruh organisasi pengelolaan zakat (OPZ) di Indonesia. ${ }^{20}$

Undang-Undang No. 23 Tahun 2011 tentang pengelolaan zakat sejalan dengan Undang-Undang RI No. 23 Tahun 2014 tentang pemerintah daerah atau sebaliknya Undang-Undang RI No. 23 Tahun 2014 tentang pemerintah daerah sejalan dengan Undang-Undang No. 23 Tahun 2011. Tujuan Undang-Undang RI No. 23 Tahun 2014 adalah penyelenggaraan pemerintahan daerah diarahkan untuk mempercepat terwujudnya kesejahteraan masyarakat melalui peningkatan pelayanan, pemberdayaan, dan peran serta masyarakat, serta peningkatan daya saing daerah dengan memperhatikan prinsip demokrasi, pemerataan, keadilan, dan kekhasan suatu daerah dalam sistem Negara Kesatuan Republik Indonesia. Sedangkan tujuan Undang-Undang No. 23 Tahun 2011 tentang pengelolaan zakat adalah meningkatkan efektivitas dan efisiensi pelayanan dalam pengelolaan zakat; dan meningkatkan manfaat zakat untuk mewujudkan kesejahteraan masyarakat dan penanggulangan kemiskinan.

Tujuan Undang-Undang No. 23 Tahun 2011 dan Undang-Undang RI No. 23 Tahun 2014 memilki kesamaan yaitu mewujudkan kesejahteraan rakyat Indonesia, di samping itu Undang-Undang RI No. 23 Tahun 2014 dapat menguatkan pelaksanaan

\footnotetext{
${ }^{19}$ Abdurahman A. Basalamah, Ekonomi Bulan Sabit, h. 1

20 Divisi Publikasi Dan Jaringan Pusat Kajian Strategis (Puskas) BAZNAS, Outlook Zakat Indonesia 2017 (Jakarta: BAZNAS 2017), h. 4.
} 
Undang-Undang No. 23 Tahun 2011. Pemerintah daerah dengan kewenangan dan kebijakannya dapat mengatur pelaksanaan pengelolaan zakat.

Pengelolaan zakat tidak dapat dipisahkan dari kewenangan pemerintah daerah sebagaimana dijelaskan dalam UU No. 23 Tahun 2011 Pasal 5 ayat 1. Aturan tersebut menjelaskan pemerintah membentuk BAZNAS selanjutnya, dalam Pasal 8 ayat 2, keanggotaan BAZNAS sebagaimana dimaksud pada ayat 2 terdiri dari 8 (delapan) orang dari unsur masyarakat dan 3 (tiga) orang dari unsur pemerintah. Pasal 15, ayat 3 , menjelaskan bahwa BAZNAS kabupaten / kota dibentuk oleh Menteri atau pejabat yang ditunjuk atas usul bupati / walikota yang menerima pertimbangan dari BAZNAS. Pasal 24 menjelaskan ruang lingkup otoritas penagihan zakat oleh BAZNAS, BAZNAS provinsi, dan BAZNAS kabupaten / kota diatur dalam Peraturan Pemerintah. Dan dalam Pasal 29 ayat 1 dari BAZNAS kabupaten / kota menyampaikan laporan tentang pelaksanaan pengelolaan zakat, infak, sedekah, dan dana sosial keagamaan lainnya kepada BAZNAS Provinsi dan pemerintah daerah secara teratur.

\section{PENUTUP}

UU No. 23 Tahun 2011 adalah dasar pelaksanaan pengelolan zakat di Indonesia. Aturan tersebut mengarahkan Pengelolaan zakat untuk meningkatkan efisiensi dan efektivitas pengelolaan zakat, dan meningkatkan manfaat bagi masyarakat dan pengentasan kemiskinan. Undang-Undang RI No. 23 Tahun 2014 tentang pemerintah daerah telah menjelaskan bahwa pemerintah daerah memiliki kewenangan dalam mengurus daerah sendiri sepanjang kebijakan pemerintah daerah tidak bertentangan dengan aturan lain. Otonomi daerah mengarahkan pada kemandirian pemerintah, masyarakat dalam meningkatkan produktivitas pelayanan dan produktivitas ekonomi pemerintah dan masyarakat, sehingga tercipta masyarakat yang makmur dan sejahtera. Undang-Undang No. 23 Tahun 2011 dan Undang-Undang RI No. 23 Tahun 2014 memilki kesamaan yaitu mewujudkan kesejahteraan rakyat Indonesia, di samping itu Undang-Undang RI No. 23 Tahun 2014 dapat menguatkan pelaksanaan UndangUndang No. 23 Tahun 2011. Pemerintah daerah dengan kewenangan dan kebijakannya dapat mengatur pelaksanaan pengelolaan zakat. 
Undang-Undang RI No. 23 Tahun 2014 Tentang Pemerintahan Daerah akan memainkan peran dengan memaksimalkan tugas dan tanggung jawab pemerintah untuk terlibat secara maksimal dalam meningkatkan kinerja BAZNAS/LAZ dan meningkatkan kepatuhan umat untuk membanyar zakat, salah satu yang dapat dilakukan pemerintah daerah yaitu mengeluarkan PERDA Zakat yang mengajur kewajiban membanyar zakat di BAZNAS, dan sanksi terhadap muzakki yang tidak membanyar zakat.

\section{DAFTAR PUSTAKA}

Bahesyti, Muhammad Husaini Dan Jawad Bahonar, Intisari Islam Kajian Komprehensif Tentang Hikmah Ajaran Islam. Cet. 1. Jakarta; Lentera, 2003.

Basalamah, Abdurahman A., Ekonomi Bulan Sabit, Gerakan Pembagunan Dalam Konsep Islam. Ujung Pandang; PT. Umitoha Ukhuwah Grafika, 1996.

Chasani, Ichwan. Judul Potensi Zakat Rp217 Triliun Bisa Dongkrak Pertumbuhan Ekonomi, http://wartakota.tribunnews.com/2017/07/26/potensi-zakat-rp217triliun-bisa-dongkrak-pertumbuhan-ekonomi, diakses pada tanggal 10 Maret 2018

Cyril Glasse, Ensiklopedi Islam (Ringkas) Cyril Glasse, Cet. 3. Jakarta; PT. Raja Grafindo Persada, 2002.

Dewan Redaksi Ensiklopedi Islam, Ensiklopedi Islam. Cet. 3. Jakarta: Ictiar Baru Van Hoeve, 1994.

Divisi Publikasi Dan Jaringan Pusat Kajian Strategis (Puskas) BAZNAS, Outlook Zakat Indonesia 2017. Jakarta: BAZNAS 2017.

Majma' Lughah Al-Arabiyah, Mu'jam Al-Wasit, Juz I. Mesir; Dar Al-Ma'arif, 1972.

Makhfudz, M, Kontroversi Pelaksanaan Otonomi Daerah. Adil : Jurnal Hukum Vol. 3 No.2, h. 380

Mohamad, Nor Sahida, Pembangunan Menurut Perspektif Islam: Satu Analisis Awalan (Development from Islamic Perspective: An Interim Analysis), Prosiding Persidangan Kebangsaan Ekonomi Malaysia Ke VIII JILID 1. 2013.

Murjana, I Made, Pelaksanaan Dan Permasalahan Otonomi Daerah Menurut UndangUndang No.32 Tahun 2004 (Tinjauan Teoritis) Ganeç Swara Vol. 10 No.1 Maret 2016 
Ristanti, Yulia Devi Dan Eko Handoyo, Undang-Undang Otonomi Daerah Dan Pembangunan Ekonomi Daerah. Jurnal Riset Akutansi Keuangan Volume 2 No.2 April 2017

Salim, Abd Muin, Ekonomi Dalam Perspektif Al-Qur'an, Sebuah Pengantar Pengenalan Dasar Ekonomi Islam,. Ujung Pandang; Yayasan Kesejahteraan Islam YAKIS Syariah, 1994.

Chapra, M. Umer, Islam Dan Tantangan Ekonomi; Islam Ekonomi Konterporer. Surabaya; Risalah Gusti, 1999. 